\title{
Advances in Pathogenesis and Management of Pruritus in Cholestasis
}

\author{
Andreas E. Kremer ${ }^{a}$ Ruth Bolier ${ }^{b}$ Remco van Dijk ${ }^{b}$ Ronald P.J. Oude Elferink ${ }^{b}$ \\ Ulrich Beuers ${ }^{\text {b }}$ \\ aDepartment of Medicine 1, Friedrich Alexander University of Erlangen-Nuremberg, Erlangen, Germany; \\ bTytgat Institute for Liver and Intestinal Research, Department of Gastroenterology and Hepatology, \\ Academic Medical Center, University of Amsterdam, Amsterdam, The Netherlands
}

\section{Key Words}

Autotaxin · Bile salt · Cholestasis · Liver · Pruritus

\begin{abstract}
Chronic pruritus is a burdensome feature of numerous hepatobiliary disorders such as primary biliary cirrhosis, primary sclerosing cholangitis, cholangiocarcinoma, inherited forms of cholestasis and intrahepatic cholestasis of pregnancy. Bile salts, $\mu$-opioids, serotonin, histamine and steroids have been controversially discussed in the pathogenesis of cholestatic pruritus. However, for these substances neither a correlation with itch severity nor a causative link has ever been established. Recent findings indicate that the potent neuronal activator lysophosphatidic acid and autotaxin, the enzyme forming lysophosphatidic acid, may play a key element in the pathogenesis of cholestatic pruritus. Serum activity of autotaxin correlated with itch intensity and response to antipruritic treatment in patients with cholestatic pruritus, but not other forms of pruritus. Autotaxin activity thereby represents the first biomarker for pruritus and had a positive predictive value of $70 \%$ in differentiating cholestatic pruritus from other forms of pruritus. Treatment options for patients with cholestatic pruritus include the anion exchange resin colestyramine, the PXR agonist rifampicin, the
\end{abstract}

$\mu$-opioid antagonist naltrexone, and the serotonin reuptake inhibitor sertraline. These drugs are recommended by evidence-based guidelines as a stepwise therapeutic approach. Patients unresponsive to these drugs should be referred to specialized centers to receive experimental approaches such as UVB phototherapy, albumin dialysis, plasmapheresis or nasobiliary drainage. This review discusses pruritogen candidates in cholestasis, gives novel insights into the neuronal signaling pathway of pruritus and summarizes evidence-based treatment options for patients suffering from pruritus in cholestasis.

๑) 2014 S. Karger AG, Basel

\section{Introduction}

Chronic pruritus is a sensory phenomenon accompanying a broad range of systemic disorders including metabolic and endocrine diseases, hematologic and lymphoproliferative disorders, solid tumors, and infectious diseases $[1,2]$. In hepatobiliary diseases, pruritus particularly accompanies those disorders with cholestatic features [3-5]. In these disorders, cholestasis may be caused by a pure hepatocellular secretory failure (hepatocellular cholestasis), cholangiocellular cholestasis

\section{KARGER}

E-Mail karger@karger.com

www.karger.com/ddi
(C) 2014 S. Karger AG, Basel

0257-2753/14/0325-0637\$39.50/0
Andreas E. Kremer, MD, Department of Medicine 1

Gastroenterology, Hepatology, Pneumology and Endocrinology

Friedrich Alexander University of Erlangen-Nuremberg

Ulmenweg 18, DE-91054 Erlangen (Germany)

E-Mail andreas.kremer@uk-erlangen.de 
with intrahepatic bile duct damage or cholestasis due to obstruction of the intrahepatic or extrahepatic bile duct system $[3,6]$. Interestingly, the prevalence of pruritus varies considerably between these hepatobiliary disorders. Pruritus is the defining symptom of women suffering from intrahepatic cholestasis of pregnancy (ICP) [7] and is experienced by up to $70-80 \%$ of patients with primary biliary cirrhosis (PBC) and primary sclerosing cholangitis at any time during the course of their disease [8-11]. In contrast, pruritus is less frequently reported by patients with obstructive cholestasis [12], or chronic hepatitis C infections [13-15]. Noteworthy, itch is not or only rarely associated with chronic hepatitis B infection, parenteral nutrition-induced cholestasis, biliary hamartomas, Caroli syndrome, congenital liver fibrosis, alcoholic or non-alcoholic fatty liver disease [(N)AFLD], or alcoholic or non-alcoholic steatohepatitis [(N)ASH] even if cholestasis is present [16].

\section{Clinical Picture}

Although often undervalued by clinicians, pruritus represents a major burden of cholestatic patients and can dramatically reduce quality of life. Pruritus may be mild and tolerable, but does in some patients limit daily life activities, cause severe sleep deprivation resulting in lassitude, fatigue, depressed mood and even suicidal sensation. In rare cases, intractable pruritus may become a primary indication for liver transplantation [17-20].

One characteristic feature of cholestatic pruritus is its circadian rhythm with patient's reporting the highest intensity in the evening hours and early at night [6]. A diurnal variation of itch intensity has been objectified by measuring the scratching intensity in $\mathrm{PBC}$ patients using piezo-film technology [10]. Another specific feature is its localization at the limbs and in particular at the palms and soles, but cholestatic pruritus is often reported to be generalized [10, 21]. Female cholestatic patients commonly report pruritus worsening during the progesterone phase of the menstrual cycle, in late pregnancy, and during hormone replacement therapy $[6,22]$. In multivariate analysis, serum alkaline phosphatase and the Mayo risk score were found to be independent indicators for the occurrence of pruritus in $\mathrm{PBC}$ patients [23].

In contrast to dermatological pruritus, primary skin lesions are not detectable in these patients; however, intense scratching activity may cause secondary skin alterations such as excoriations and prurigo nodularis [24]. Although secondary skin lesions may be difficult to discrim- inate from primary skin disorders, if no scratch tools are used, the so-called 'butterfly sign' points to a non-dermatological cause of chronic pruritus. This sign is defined as unaffected skin at the upper patient's back due to difficulties to manually reach that part of the body. Furthermore, typical skin signs of chronic liver disorders such as jaundice, spider naevi, palmar erythema or leukonychia may help to identify the underlying cause.

\section{Pathogenesis}

In spite of the growing knowledge of receptors and pathways responsible for acute itch signaling in mice, rats and other species [25-27] as outlined below, the responsible ligands and receptors for itch sensation in human beings remain unsolved for most disorders associated with chronic pruritus [28]. The pathogenesis of pruritus in cholestasis remains likewise enigmatic. Several potential itch-causing substances including bile salts, endogenous $\mu$-opioids, histamine, serotonin and steroids have been controversially discussed. However, for these substances neither a correlation between serum and/or tissue concentrations and itch severity nor a causative link have ever been established $[5,23]$. Thus, these substances rather seem not to be direct itch-causing molecules, although some might modulate the neuronal signaling cascade leading to the desire to scratch. For detailed rationale in favor or against these substances, the reader is referred to previous reviews $[5,29]$. The current review highlights novel insights in the bile salt G-protein-coupled receptor TGR5 and lysophosphatidic acid (LPA) as well as the neuronal itch signaling pathway.

\section{Potential Pruritogens}

Clinical and experimental observations indicate that the itch-causing molecules in cholestasis accumulate in the systemic circulation as suggested by attenuation of pruritus after treatment with plasmapheresis or albumin dialysis. The pruritogens are secreted into bile as indicated by rapid relief of severe, treatment-refractory pruritus after nasobiliary drainage. Furthermore, the itch-inducing substances are (biotrans)formed in liver and/or gut as indicated by effective treatment with the potent pregnane X receptor (PXR) agonist rifampicin. Finally, the pruritogens of cholestasis affect the endogenous opioidergic and serotoninergic system as suggested by moderate antipruritic activity of $\mu$-opioid antagonists and selective serotonin reuptake inhibitors $[3,5]$. It was our hypothesis that itch-causing molecules during cholestasis 
accumulate in serum, which should be capable of activating neuronal cells. We therefore screened sera of cholestatic patients with and without pruritus for the capacity of neuronal activation. Indeed, in a human neuroblastoma cell line sera of cholestatic patients caused a dose-dependent transient rise in cytosolic free calcium concentrations [30]. The main neuronal activator could be unraveled as a potent lipid mediator, LPA. LPA levels were increased in women with ICP compared to gestationmatched women with uncomplicated pregnancy [30]. Intradermal injection of LPA caused a dose-dependent scratching behavior in mice confirming a previous mouse study $[30,31]$.

Extracellular LPA is mainly synthesized from its precursor molecule lysophosphatidylcholine (LPC) by the lysophospholipase D, also named autotaxin (ATX) $[32,33]$. LPC is present in high micromolar concentrations in plasma and LPA levels largely depend on the amount of ATX as shown in heterozygous mice $\left(\mathrm{ATX}^{+/-}\right)$[34]. The enzyme ATX is the second member of the family of ectonucleotide pyrophosphatases/phosphodiesterases(ENPP) and also entitled as ENPP2. The affinity of ATX for nucleotides is however much lower compared to lysophospholipids [35]. ATX plays a critical role in diverse physiological conditions such as vascular and neuronal development, during pregnancy or for lymphocyte migration. Furthermore, ATX influences several pathophysiological states including neuropathic pain, cardiovascular diseases, pulmonary fibrosis, cancer development and formation of metastases [36]. Our studies have added a role of ATX in cholestatic pruritus. Serum ATX activity and ATX protein content were markedly increased in sera of ICP women compared to gestation-matched pregnant controls and in sera of cholestatic patients with compared to those without pruritus [37]. Furthermore, in contrast to other putative pruritogens such as serum bile salt levels or serum $\mu$-opioid activity, serum ATX activity correlated with the actual itch intensity in these patients [37]. Also, the decline in ATX levels correlated with treatment efficacy of several medicinal and invasive therapeutic interventions such as colesevelam, rifampicin, molecular adsorbents recirculating system (MARS ${ }^{\circledR}$ ) therapy and nasobiliary drainage [38]. ATX activity again returned to higher levels when pruritus relapsed in patients weeks to months after cessation of MARS therapy or nasobiliary drainage $[38,39]$. Rifampicin was found to reduce ATX expression at the transcriptional level in human liver-derived cell lines by a PXR-dependent mechanism, possibly explaining the strong antipruritic effect of rifampicin in clinical practice at least in part [38].

Advances in Pathogenesis and

Management of Pruritus in Cholestasis
Serum ATX activity was higher in patients with pruritus of cholestasis compared to patients with pruritus due to chronic kidney disease, Hodgkin's disease or atopic dermatitis [38]. Autotaxin activity had a positive predictive value of $70 \%$ in differentiating cholestatic pruritus from pruritus associated with atopic dermatitis, uremia and Hodgkin lymphoma. Thus, ATX represents the first biomarker for a chronic itch condition and might represent a useful diagnostic tool for those cases in whom chronic pruritus remains unclassified [38].

These novel insights into the pathogenesis of cholestatic pruritus raise new questions. First of all, the source of the circulating ATX levels remains to be elucidated. Interruption of the enterohepatic circulation by nasobiliary drainage caused a rapid drop of circulating levels of ATX concomitant with relief of pruritus [30,38]. As ATX is not secreted into bile [30], a factor within the enterohepatic circulation may be responsible for the increased serum ATX levels. Preliminary data from our laboratory point to the human small intestine as source of ATX [Bolier et al., in preparation]. Which molecules are involved in the regulation of ATX gene expression is an unresolved question. In that regard, steroids may play a role as autotaxin gene expression was upregulated in the hippocampus of ovariectomized rats upon treatment with estrogen [40]. Intake of oral contraceptives was associated with increased serum ATX levels in healthy female individuals [Kremer et al., in preparation]. Thus, steroids may particularly in pregnancy and ICP be responsible for increased ATX levels. A further issue is the molecular mechanism of LPA-induced scratching behavior as outlined below.

Bile salts have been implicated in the pathogenesis of cholestatic pruritus almost since their discovery $[5,41]$. Bile salts mediate their effects via the nuclear transcription factor farnesoid X receptor (FXR) or the transmembrane G-protein-coupled receptor TGR5 [42]. Upon binding to these receptors, bile salts are capable of activating complex transcriptional networks and intracellular signaling cascades. Activation of FXR has proven various beneficial effects in different pathophysiological states including cholestasis, liver fibrosis, non-alcoholic steatohepatitis and hepatocellular carcinoma [42, 43]. The semisynthetic bile salt obeticholate (6-ethyl-chenodeoxycholate) is a selective FXR ligand which is currently studied in clinical trials in patients with PBC and NASH [44]. This drug exerted beneficial anticholestatic effects in PBC; however, it caused pruritus particularly at high doses [44]. The underlying mechanism remains elusive. Recently, TGR5 was suggested to play a role in bile salt-me- 
diated pruritus and analgesia [45]. TGR5 was detected in peptidergic neurons of mouse dorsal root ganglia, pointing out a possible role in sensory circuits. Indeed, intradermal injection of high concentrations of the bile salts deoxycholate and lithocholate induced scratching behavior which was attenuated in TGR $5^{-/-}$mice and augmented in TGR5 transgenic mice [45]. However, the applied concentrations of these hydrophobic bile salts were far beyond the pathophysiological levels observed in cholestatic disorders such as PBC or ICP which are associated with pruritus. These disorders are characterized by a depleted deoxycholic acid (DCA) pool size [46] with barely detectable concentrations of unconjugated DCA in serum and bile. Still, other agonists of TGR 5 such as neurosteroids might be capable of activating this receptor leading to itch sensation. Notably, progesterone has recently been shown to activate TGR5 in placental tissue in a dosedependent manner [47].

\section{Neuronal Itch Signaling}

Itch sensation depends on a complex interplay of pruritogens, their receptors on peripheral sensory nerve fibers, intraspinal and cerebral neural pathways, as well as cerebral processing of the stimuli. The discovery of sensory nerve fibers responsive to histamine but insensitive to certain algesic stimuli such as mechanical pain revolutionized pruritus research 15 years ago [48]. Still, these neurons can be activated by the algogen and TRPV1 agonist capsaicin. Thus, the question remained whether sensory neurons exist that exclusively mediate itch sensation. Only recently, a very elegant study presented evidence that a small subpopulation of sensory neurons expressing the Mas-related G-protein-coupled receptor subtype A3 (MrgA3) could represent such neurons [49]. Ablation of these MrgA3-positive neurons strongly attenuated scratching behavior in mice to most intradermally applied pruritogens. In mice lacking the TRPV1 channel, re-expression of TRPV1 only in MrgA3-positive neurons revealed that the algogen capsaicin largely caused scratching behavior but hardly any pain-related wiping [49]. Thus, irrespective of the modality of activation, these neurons seem to induce itch sensation but no pain. Still, pain and itch signaling are closely intertwined processes: activation of pain neurons abrogates itch sensation, e.g. by scratching, cooling or heating of the skin $[1,50]$. Analgetics may induce itch sensation, e.g. by epidural or intrathecal application of opioids or anesthetics [51-53]. This can be explained by an itch circuitry which is under a tonic inhibitory control of mechanosensitive neurons (fig. 1). Evidence for such an inhibitory control was sup- ported by the observation of spontaneous intense scratching behavior in mice lacking certain inhibitory, Bhlbh5and Prdm8-expressing interneurons $[54,55]$. These interneurons are believed to be activated by glutamate. Deletion of the glutamate transporter VGLUT2 caused increased spontaneous and induced scratching behaviors after application of pruritogens which underlined this hypothesis [56, 57].

Beside Mas-related G-protein-coupled receptor subtype A3 (MrgA3) which is activated by chloroquine [58], other receptors have been implicated in the onset of pruritus. Among these are the MrgD for $\beta$-alanine [59], the $\mu$-opioid receptor $1 \mathrm{D}$ for morphine-induced pruritus [60], endothelin-A receptor for endothelin-1 [61], as well as the interleukin-13 [62] and interleukin-31 receptor [63]. Activation of these receptors results in opening of transient receptor potential (TRP) receptors such as the vanilloid-1 receptor (TRPV1) or ankyrin-1 channel (TRPA1) on sensory neurons $[49,64]$. Primary sensory neurons signal to the dorsal horn of the spinal cord where secondary neurons are activated by release of glutamate and neuropeptide natriuretic polypeptide b (Nppb) [65]. Secondary neurons express natriuretic peptide receptor A (NprA, the receptor for Nppb) and were suggested to release gastrin releasing peptide (GRP) which activates the GRP receptor of a third neuron in the spinal cord (fig. 1) [65-67]. Ablation of either the NrpA or GRP receptor expressing neurons by intrathecal application of a toxin bound to the respective signaling molecule largely abolished scratching behavior after intradermal application of various pruritogens $[65,67]$. Noteworthy, pain responses were unaltered after ablation of these neurons, indicating that a selective itch pathway exists on spinal cord level [65, 67].

The molecular mechanisms of LPA-induced scratching behavior still remain to be elucidated. LPA is synthesized by ATX and may act via at least six G-protein-coupled receptors for LPA $\left(\mathrm{LPA}_{1-6}\right)[35,68]$. These receptors are present in various tissues including the nervous system. LPA can induce neuropathic pain via $\mathrm{LPA}_{1}, \mathrm{LPA}_{3}$ and $\mathrm{LPA}_{5}$ receptors [69]. LPA was recently suggested to also directly activate the transient receptor potential vanilloid receptor subfamily V1 (TRPV1) and may thereby mediate neuropathic pain [70]. Intracellularly applied LPA activated TRPV1 considerably faster and stronger than extracellular LPA via an intracellular binding site on TRPV1 [70]. As LPA contains a charged phosphate group, it cannot easily cross the plasma membrane and it remains to be shown how relevant this type of activation is with regard to extracellularly generated LPA. 


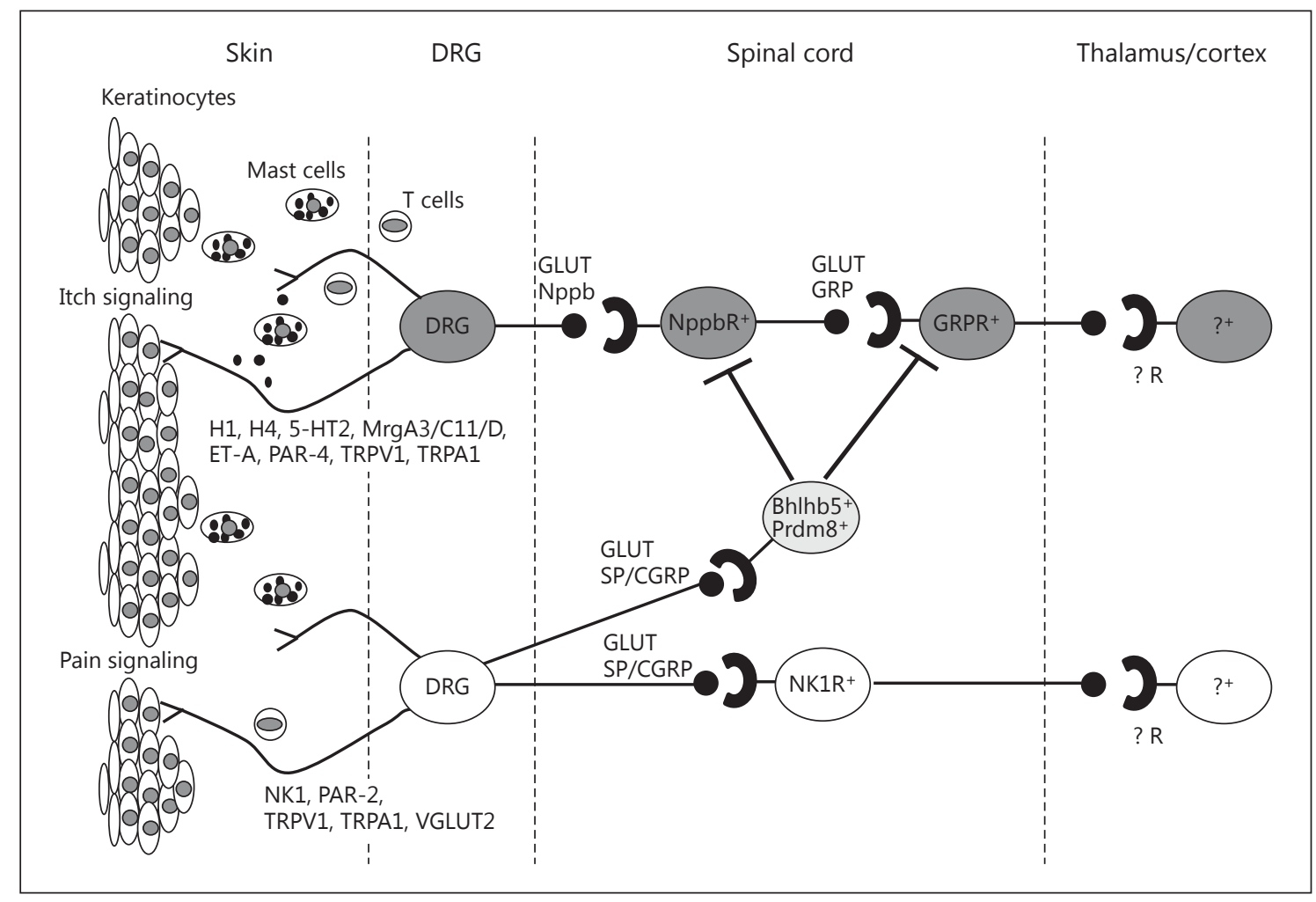

Fig. 1. Neuronal itch signaling. Simplified scheme of pain and itch signaling pathways from the peripheral to the central nervous system and their interaction. Itch- and pain-causing molecules bind to specific receptors on sensory nerve endings in the epidermis or dermis. Among the established receptors for itch signaling are histamine (H1, H4), serotonin (5-HT2), Mas-gene-related G-protein-coupled receptors (MrgA3, MrgC11, MrgD), endothelin (ETA), protease-activated receptor (PAR-4), and interleukin-31. These neurons also express transient receptor potential (TRP) receptors such as TRPV1 and TRPA1. Pruritus may also be initiated or potentiated by LPA receptors. Synaptic signal transmission from the peripheral sensory neuron to the secondary neuron in the dorsal horn of the spinal cord is mediated by glutamate (GLUT)

Which LPA receptor and intracellular signaling pathway is required for LPA-induced pruritus warrants further investigation.

\section{Management}

Current treatment recommendations for pruritus in cholestasis are based on only a few well-designed, randomized, placebo-controlled trials and several cohort studies [3]. The rationale for medical and interventional therapeutic approaches is (i) to remove the pruritogen(s) from the enterohepatic cycle by non-absorbable, anion and natriuretic polypeptide $\mathrm{b}(\mathrm{Nppb})$. Gastrin-releasing peptide (GRP) and GLUT may be involved in signal transmission to the tertiary neuron. The neuronal itch signaling pathway is under inhibitory control of the pain signals (as indicated by the Bhlhb5and Prdm8-expressing interneurons). Pain sensation is similarly perceived by receptors on peripheral sensory neurons including neurokinin-1 (NK1) for substance P (SP) or protease-activated receptor 2 (PAR-2) for proteases. Synaptic signal transmission from the peripheral sensory neuron to the secondary pain neurons and interneurons in the dorsal horn of the spinal cord is presumably mediated by GLUT, SP, and calcitonin gene-related peptide (CGRP).

exchange resins such as cholestyramine in mild pruritus or invasive interventions such as nasobiliary and transcutaneous drainage or external biliary diversion in desperate cases; (ii) to alter the metabolism of the presumed pruritogen(s) in the liver and/or the intestine by inducers of the hepatic biotransformation machinery such as rifampicin; (iii) to modulate central itch and/or pain signaling by influencing the endogenous opioidergic and serotoninergic system via $\mu$-opioid antagonists and selective serotonin re-uptake inhibitors (SSRI), respectively, or (iv) to remove the potential pruritogen(s) from the systemic circulation by invasive methods such as anion absorption, plasmapheresis or extracorporeal albumin di- 
Table 1. Therapeutic recommendations for the management of pruritus in cholestasis [3]

\begin{tabular}{|c|c|c|c|}
\hline Approach & Drug/therapy ${ }^{\mathrm{a}}$ & Dosage & Evidence \\
\hline ICP only & $\mathrm{UDCA}^{\mathrm{b}}$ & $10-15 \mathrm{mg} / \mathrm{kg} /$ day (p.o.) & $\mathrm{I} / \mathrm{B} 1^{\mathrm{b}}$ \\
\hline 1st line & Cholestyramine & 4-16 g/day (p.o.) & II-2/B1 \\
\hline 2nd line & Rifampicin & $300-600 \mathrm{mg} /$ day (p.o.) & $\mathrm{I} / \mathrm{A} 1$ \\
\hline 3rd line & Naltrexone & 50 mg/day (p.o.) & $\mathrm{I} / \mathrm{B} 1$ \\
\hline 4th line & Sertraline & 100 mg/day (p.o.) & II-2/C2 \\
\hline
\end{tabular}

\begin{tabular}{ll}
\multicolumn{2}{l}{ Categories of evidence } \\
I & Randomized controlled trials \\
II-1 & Controlled trials without randomization \\
II-2 & Cohort or case-control analytic studies \\
II-3 & Multiple time series, dramatic uncontrolled experiments \\
III & Opinions of respected authorities, descriptive epidemiology
\end{tabular}

\section{Evidence grading \\ A High quality: further research is very unlikely to change our confidence in the estimate of effect \\ B Moderate quality: further research is likely to have an important impact on our confidence in the estimate of effect and may change the estimate \\ C Low quality: further research is very likely to have an important impact on our confidence in the estimate of effect and is likely to change the estimate; any change of estimate is uncertain}

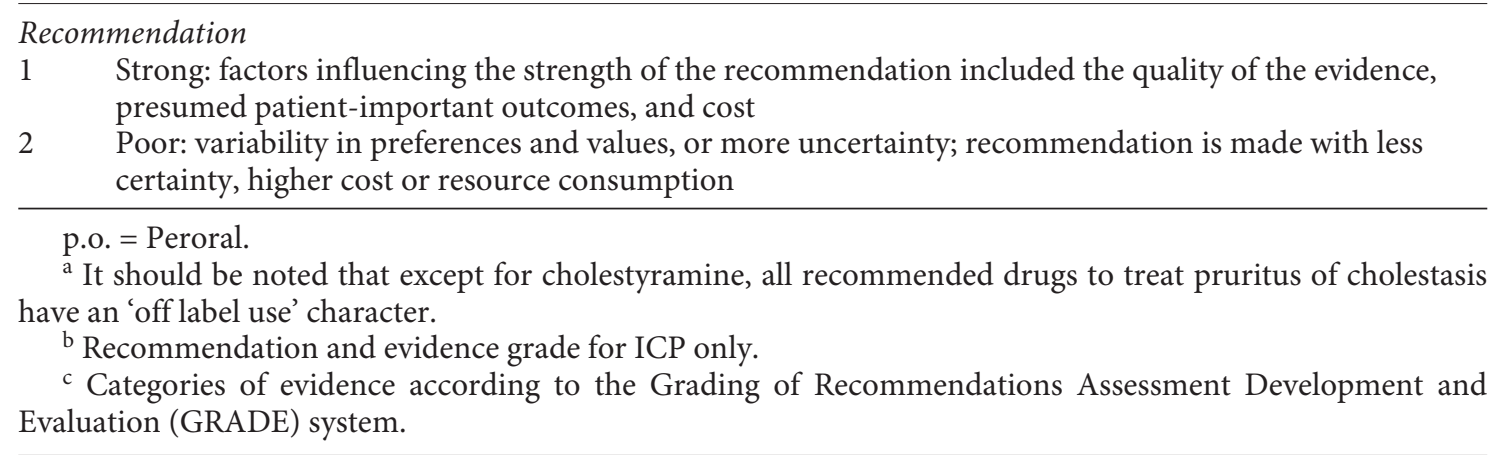

alysis if pruritus is intractable (table 1) [3]. It should be noted that except for cholestyramine, all recommended drugs to treat pruritus of cholestasis have an 'off label use' character.

Ursodeoxycholic acid (UDCA, $10-15 \mathrm{mg} / \mathrm{kg} /$ day) exerts beneficial anticholestatic effects [71] and represents therefore a baseline therapy for several cholestatic disorders including PBC, cystic fibrosis-associated liver disease, pediatric cholestatic syndromes and ICP. Several case series reported UDCA to effectively attenuate pruritus in some pediatric cholestatic disorders [72-74]. In ICP, UDCA convincingly improved pruritus and serum liver tests in several randomized, placebo-controlled trials and is regarded as first-line treatment $[3,75]$. This well-tolerated drug has been studied in several other chronic cholestatic disorders, but never with regard to itch as primary endpoint $[23,76]$.
In pruritus of all other forms of intrahepatic cholestasis and extrahepatic forms in which bile flow cannot be restored by invasive procedures, anion exchange resins are recommended as first-line treatment. Beneficial effects for cholestyramine have been reported in several small uncontrolled case series [77-84]. Cholestyramine is recommended as a 4 -gram sachet $1 \mathrm{~h}$ before and after breakfast and may be extended to $16 \mathrm{~g} /$ day. Resins should be taken at least $4 \mathrm{~h}$ prior to any other medication as they may interfere with their intestinal absorption. In a recent randomized, placebo-controlled trial, colesevelam, which has a higher binding affinity for bile salts than cholestyramine, failed to be superior to placebo [85]. Although cholestyramine may theoretically bind the 'real' itch-causing molecules more efficiently in the gut lumen than colesevelam, these results weaken the position of resins in the treatment recommendations 
and underline the importance of randomized, placebocontrolled trials.

If resins are ineffective, the PXR agonist, rifampicin, is regarded as second-line treatment (table 1). Four prospective, randomized, placebo-controlled trials have proven the antipruritic efficacy of rifampicin [86-89]. Rifampicin is a safe short-term therapy of cholestatic pruritus; however, hepatotoxicity may occur in up to $13 \%$ of patients after treatment for several weeks or months [89] requiring the monitoring of serum transaminase levels at regular intervals. If rifampicin is ineffective within 2 weeks, the $\mu$-opioid antagonist naltrexone is recommended as third-line treatment. Naltrexone moderately improved pruritus at doses of $25-50 \mathrm{mg}$ /day in four small placebo-controlled trials [90-93]. Adverse effects may include withdrawal-like reactions, particularly during the first days of therapy. Therefore, naltrexone should be administered at low doses of $12.5 \mathrm{mg} /$ day or intravenous infusion of naloxone followed by a stepwise dose increase. The selective serotonin uptake inhibitor sertraline (75$100 \mathrm{mg} /$ day) can be administered as fourth-line therapy. A single placebo-controlled crossover trial [94] and a case series [95] reported moderate antipruritic effects. Coadministration of several drugs at the same time is not recommended due to the risk of drug-drug interactions.
Using this stepwise approach pruritus will improve in most patients. Experimental approaches such as UVB phototherapy, albumin dialysis, plasmapheresis or nasobiliary drainage may be considered in those patients not adequately responding to standard care and should be performed in specialized medical centers. Only if all evidence-based and experimental therapies have failed liver transplantation can be regarded as the very last desperate therapeutic step.

\section{Conclusion}

Cholestatic pruritus is a debilitating symptom of various hepatobiliary disorders. We still scratch on the surface of the complex molecular mechanisms responsible for this enigmatic symptom. Further insights into the signaling cascade of itch sensation in cholestasis will open new avenues for the development of more effective treatment strategies among which LPA receptor antagonists and ATX inhibitors may be of significance.

\section{Disclosure Statement}

The authors have no conflicts of interest to disclose.

\section{References}

1 Yosipovitch G, Bernhard JD: Clinical practice. Chronic pruritus. N Engl J Med 2013; 368:1625-1634.

2 Paus R, Schmelz M, Biro T, Steinhoff M: Frontiers in pruritus research: scratching the brain for more effective itch therapy. J Clin Invest 2006;116:1174-1186.

3 EASL Clinical Practice Guidelines: Management of cholestatic liver diseases. J Hepatol 2009;51:237-267.

-4 Lindor KD, Gershwin ME, Poupon R, Kaplan M, Bergasa NV, Heathcote EJ: Primary biliary cirrhosis. Hepatology 2009;50:291-308.

5 Kremer AE, Oude Elferink RP, Beuers U: Pathophysiology and current management of pruritus in liver disease. Clin Res Hepatol Gastroenterol 2011;35:89-97.

-6 Kremer AE, Beuers U, Oude-Elferink RP, Pusl T: Pathogenesis and treatment of pruritus in cholestasis. Drugs 2008;68:2163-2182.

7 Geenes V, Williamson C: Intrahepatic cholestasis of pregnancy. World J Gastroenterol 2009;15:2049-2066.

\footnotetext{
8 Sherlock S, Scheuer PJ: The presentation and diagnosis of 100 patients with primary biliary cirrhosis. N Engl J Med 1973;289:674-678.

-9 James O, Macklon AF, Watson AJ: Primary biliary cirrhosis - a revised clinical spectrum. Lancet 1981;1:1278-1281.

10 Bergasa NV, Mehlman JK, Jones EA: Pruritus and fatigue in primary biliary cirrhosis. Baillieres Best Pract Res Clin Gastroenterol 2000; 14:643-655.

11 Koulentaki M, Ioannidou D, Stefanidou M, Maraki S, Drigiannakis I, Dimoulios P, Melono JM, Tosca A, Kouroumalis EA: Dermatological manifestations in primary biliary cirrhosis patients: a case-control study. Am J Gastroenterol 2006;101:541-546.

12 McPhedran NT, Henderson RD: Pruritus and jaundice. Can Med Assoc J 1965;92:12581260.

13 Cribier B, Samain F, Vetter D, Heid E, Grosshans E: Systematic cutaneous examination in hepatitis C virus infected patients. Acta Derm Venereol 1998;78:355-357.

14 Chia SC, Bergasa NV, Kleiner DE, Goodman Z, Hoofnagle JH, Di Bisceglie AM: Pruritus as a presenting symptom of chronic hepatitis C. Dig Dis Sci 1998;43:2177-2183.

$\checkmark 15$ Cacoub P, Poynard T, Ghillani P, Charlotte F, Olivi M, Piette JC, Opolon P: Extrahepatic manifestations of chronic hepatitis C. MULTIVIRC Group. Multidepartment Virus C. Arthritis Rheum 1999;42:2204-2212.

16 Ghent CN, Bloomer JR: Itch in liver disease: facts and speculations. Yale J Biol Med 1979; 52:77-82.

17 Elias E, Burra P: Primary biliary cirrhosis: symptomatic treatment. J Gastroenterol Hepatol 1991;6:570-573.

18 Elias E: Liver transplantation. J R Coll Physicians Lond 1993;27:224-232.

19 Heathcote EJ: Management of primary biliary cirrhosis. The American Association for the Study of Liver Diseases practice guidelines. Hepatology 2000;31:1005-1013.

20 Neuberger J, Jones EA: Liver transplantation for intractable pruritus is contraindicated before an adequate trial of opiate antagonist therapy. Eur J Gastroenterol Hepatol 2001;13: 1393-1394.
}

Advances in Pathogenesis and

Management of Pruritus in Cholestasis 
21 Pusl T, Beuers U: Ursodeoxycholic acid treatment of vanishing bile duct syndromes. World J Gastroenterol 2006;12:3487-3495.

22 Bergasa NV: The pruritus of cholestasis. J Hepatol 2005;43:1078-1088.

-23 Talwalkar JA, Souto E, Jorgensen RA, Lindor KD: Natural history of pruritus in primary biliary cirrhosis. Clin Gastroenterol Hepatol 2003;1:297-302.

24 Swain MG: Pruritus and lethargy in the primary biliary cirrhosis patient; in Neuberger J (ed): Primary Biliary Cirrhosis. Eastbourne, West End Studios, 1999, pp 75-81.

25 McNeil B, Dong X: Peripheral mechanisms of itch. Neurosci Bull 2012;28:100-110.

-26 Cevikbas F, Steinhoff M, Ikoma A: Role of spinal neurotransmitter receptors in itch: new insights into therapies and drug development. CNS Neurosci Ther 2011;17:742-749.

27 LaMotte RH, Shimada SG, Sikand P: Mouse models of acute, chemical itch and pain in humans. Exp Dermatol 2011;20:778-782.

-28 Yosipovitch G, Greaves MW, Schmelz M: Itch. Lancet 2003;361:690-694.

29 Bergasa NV: The itch of liver disease. Semin Cutan Med Surg 2011;30:93-98.

- 30 Kremer AE, Martens JJ, Kulik W, Rueff F, Kuiper EM, van Buuren HR, van Erpecum KJ, Kondrackiene J, Prieto J, Rust C, Geenes VL, Williamson C, Moolenaar WH, Beuers U, Oude Elferink RP: Lysophosphatidic acid is a potential mediator of cholestatic pruritus. Gastroenterology 2010;139:1008-1018.

- 31 Hashimoto T, Ohata H, Momose K: Itchscratch responses induced by lysophosphatidic acid in mice. Pharmacology 2004;72:5156.

-32 Tokumura A, Majima E, Kariya Y, Tominaga K, Kogure K, Yasuda K, Fukuzawa K: Identification of human plasma lysophospholipase D, a lysophosphatidic acid-producing enzyme, as autotaxin, a multifunctional phosphodiesterase. J Biol Chem 2002;277:3943639442.

33 Umezu-Goto M, Kishi Y, Taira A, Hama K, Dohmae N, Takio K, Yamori T, Mills GB, Inoue $\mathrm{K}$, Aoki J, Arai H: Autotaxin has lysophospholipase $\mathrm{D}$ activity leading to tumor cell growth and motility by lysophosphatidic acid production. J Cell Biol 2002;158:227-233.

- 34 Tanaka M, Okudaira S, Kishi Y, Ohkawa R, Iseki S, Ota M, Noji S, Yatomi Y, Aoki J, Arai $\mathrm{H}$ : Autotaxin stabilizes blood vessels and is required for embryonic vasculature by producing lysophosphatidic acid. J Biol Chem 2006; 281:25822-25830.

35 Van Meeteren LA, Moolenaar WH: Regulation and biological activities of the autotaxinLPA axis. Prog Lipid Res 2007;46:145-160.

- 36 Moolenaar WH, Perrakis A: Insights into autotaxin: how to produce and present a lipid mediator. Nat Rev Mol Cell Biol 2011;12:674679.
37 Kremer AE, Martens JJ, Kulik W, Williamson C, Moolenaar WH, Kondrackiene J, Beuers U, Oude Elferink RP: Autotaxin but not bile salts correlate with itch intensity in cholestasis (abstract). J Hepatol 2010;52:S1

38 Kremer AE, van Dijk R, Leckie P, Schaap FG, Kuiper EM, Mettang T, Reiners KS, Raap U, van Buuren HR, van Erpecum KJ, Davies NA, Rust C, Engert A, Jalan R, Oude Elferink RP, Beuers U: Serum autotaxin is increased in pruritus of cholestasis, but not of other origin, and responds to therapeutic interventions. Hepatology 2012;56:1391-1400.

39 Kremer AE, Martens JJ, Kulik W, Rueff F, Kuiper EM, van Buuren HR, van Erpecum KJ, Kondrackiene J, Prieto J, Rust C, Geenes VL, Williamson C, Moolenaar WH, Beuers U, Oude Elferink RP: Lysophosphatidic acid is a potential mediator of cholestatic pruritus. Gastroenterology 2010;139:1008-1018.

40 Takeo C, Ikeda K, Horie-Inoue K, Inoue S: Identification of Igf2, Igfbp2 and Enpp2 as estrogen-responsive genes in rat hippocampus. Endocr J 2009;56:113-120.

41 Jones EA, Bergasa NV: The pruritus of cholestasis: from bile acids to opiate agonists. Hepatology 1990;11:884-887.

42 Schaap FG, Trauner M, Jansen PL: Bile acid receptors as targets for drug development. Nat Rev Gastroenterol Hepatol 2014;11:5567.

43 Trauner M, Baghdasaryan A, Claudel T, Fickert P, Halilbasic E, Moustafa T, Zollner G: Targeting nuclear bile acid receptors for liver disease. Dig Dis 2011;29:98-102.

44 Fiorucci S, Cipriani S, Mencarelli A, Baldelli F, Bifulco G, Zampella A: Farnesoid X receptor agonist for the treatment of liver and metabolic disorders: focus on 6-ethyl-CDCA. Mini Rev Med Chem 2011;11:753-762.

45 Alemi F, Kwon E, Poole DP, Lieu T, Lyo V, Cattaruzza F, Cevikbas F, Steinhoff M, Nassini R, Materazzi S, Guerrero-Alba R, ValdezMorales E, Cottrell GS, Schoonjans K, Geppetti P, Vanner SJ, Bunnett NW, Corvera CU: The TGR5 receptor mediates bile acid-induced itch and analgesia. J Clin Invest 2013; 123:1513-1530

-46 Beuers U, Spengler U, Zwiebel FM, Pauletzki J, Fischer S, Paumgartner G: Effect of ursodeoxycholic acid on the kinetics of the major hydrophobic bile acids in health and in chronic cholestatic liver disease. Hepatology 1992;15: 603-608.

47 Keitel V, Spomer L, Marin JJ, Williamson C, Geenes V, Kubitz R, Haussinger D, Macias RI: Effect of maternal cholestasis on TGR5 expression in human and rat placenta at term. Placenta 2013;34:810-816.

48 Schmelz M, Schmidt R, Bickel A, Handwerker HO, Torebjork HE: Specific C-receptors for itch in human skin. J Neurosci 1997;17:80038008 .
49 Han L, Ma C, Liu Q, Weng HJ, Cui Y, Tang Z, Kim Y, Nie H, Qu L, Patel KN, Li Z, McNeil B, He S, Guan Y, Xiao B, Lamotte RH, Dong $\mathrm{X}$ : A subpopulation of nociceptors specifically linked to itch. Nat Neurosci 2013;16:174182.

50 Weisshaar E, Szepietowski JC, Darsow U, Misery L, Wallengren J, Mettang T, Gieler U, Lotti T, Lambert J, Maisel P, Streit M, Greaves MW, Carmichael AJ, Tschachler E, Ring J, Stander S: European guideline on chronic pruritus. Acta Derm Venereol 2012;92:563581

51 Ballantyne JC, Loach AB, Carr DB: Itching after epidural and spinal opiates. Pain 1988;33: 149-160.

52 Ballantyne JC, Loach AB, Carr DB: The incidence of pruritus after epidural morphine. Anaesthesia 1989;44:863.

53 Atanassoff PG, Brull SJ, Zhang J, Greenquist K, Silverman DG, Lamotte RH: Enhancement of experimental pruritus and mechanically evoked dysesthesiae with local anesthesia. Somatosens Mot Res 1999;16:291-298.

54 Ross SE, Mardinly AR, McCord AE, Zurawski J, Cohen S, Jung C, Hu L, Mok SI, Shah A, Savner EM, Tolias C, Corfas R, Chen S, Inquimbert $\mathrm{P}, \mathrm{Xu} \mathrm{Y}, \mathrm{McInnes} \mathrm{RR}$, Rice FL, Corfas G, Ma Q, Woolf CJ, Greenberg ME: Loss of inhibitory interneurons in the dorsal spinal cord and elevated itch in Bhlhb5 mutant mice. Neuron 2010;65:886-898.

55 Ross SE, McCord AE, Jung C, Atan D, Mok SI, Hemberg M, Kim TK, Salogiannis J, Hu L, Cohen S, Lin Y, Harrar D, McInnes RR, Greenberg ME: Bhlhb5 and Prdm8 form a repressor complex involved in neuronal circuit assembly. Neuron 2012;73:292-303.

56 Liu Y, Abdel Samad O, Zhang L, Duan B, Tong Q, Lopes C, Ji RR, Lowell BB, Ma Q: VGLUT2-dependent glutamate release from nociceptors is required to sense pain and suppress itch. Neuron 2010;68:543-556.

57 Lagerstrom MC, Rogoz K, Abrahamsen B, Persson E, Reinius B, Nordenankar K, Olund C, Smith C, Mendez JA, Chen ZF, Wood JN, Wallen-Mackenzie A, Kullander K: VGLUT2dependent sensory neurons in the TRPV1 population regulate pain and itch. Neuron 2010;68:529-542.

58 Liu Q, Tang Z, Surdenikova L, Kim S, Patel KN, Kim A, Ru F, Guan Y, Weng HJ, Geng Y, Undem BJ, Kollarik M, Chen ZF, Anderson DJ, Dong X: Sensory neuron-specific GPCR Mrgprs are itch receptors mediating chloroquine-induced pruritus, Cell 2009;139:13531365.

59 Liu Q, Sikand P, Ma C, Tang Z, Han L, Li Z, Sun S, LaMotte RH, Dong X: Mechanisms of itch evoked by $\beta$-alanine. J Neurosci 2012;32: 14532-14537.

60 Liu XY, Liu ZC, Sun YG, Ross M, Kim S, Tsai FF, Li QF, Jeffry J, Kim JY, Loh HH, Chen ZF: Unidirectional cross-activation of GRPR by MOR1D uncouples itch and analgesia induced by opioids. Cell 2011;147:447-458. 
61 McQueen DS, Noble MA, Bond SM: Endothelin-1 activates ETA receptors to cause reflex scratching in BALB/c mice. Br J Pharmacol 2007;151:278-284.

-62 Zheng T, Oh MH, Oh SY, Schroeder JT, Glick $\mathrm{AB}, \mathrm{Zhu} \mathrm{Z}$ : Transgenic expression of interleukin-13 in the skin induces a pruritic dermatitis and skin remodeling. J Invest Dermatol 2009; 129:742-751.

63 Dillon SR, Sprecher C, Hammond A, Bilsborough J, Rosenfeld-Franklin M, Presnell SR, Haugen HS, Maurer M, Harder B, Johnston J, Bort S, Mudri S, Kuijper JL, Bukowski T, Shea P, Dong DL, Dasovich M, Grant FJ, Lockwood L, Levin SD, LeCiel C, Waggie K, Day H, Topouzis S, Kramer J, Kuestner R, Chen Z, Foster D, Parrish-Novak J, Gross JA: Interleukin-31, a cytokine produced by activated $\mathrm{T}$ cells, induces dermatitis in mice. Nat Immunol 2004;5:752-760.

-64 Wilson SR, Gerhold KA, Bifolck-Fisher A, Liu Q, Patel KN, Dong X, Bautista DM: TRPA1 is required for histamine-independent, Mas-related $\mathrm{G}$ protein-coupled receptor-mediated itch. Nat Neurosci 2011;14:595-602.

65 Mishra SK, Hoon MA: The cells and circuitry for itch responses in mice. Science 2013;340 968-971.

-66 Sun YG, Chen ZF: A gastrin-releasing peptide receptor mediates the itch sensation in the spinal cord. Nature 2007;448:700-703.

-67 Sun YG, Zhao ZQ, Meng XL, Yin J, Liu XY, Chen ZF: Cellular basis of itch sensation. Science 2009;325:1531-1534.

68 Houben AJ, Moolenaar WH: Autotaxin and LPA receptor signaling in cancer. Cancer Metastasis Rev 2011;30:557-565.

-69 Choi JW, Chun J: Lysophospholipids and their receptors in the central nervous system. Biochim Biophys Acta 2013;1831:20-32.

70 Nieto-Posadas A, Picazo-Juarez G, Llorente I, Jara-Oseguera A, Morales-Lazaro S, Escalante-Alcalde D, Islas LD, Rosenbaum T: Lysophosphatidic acid directly activates TRPV1 through a C-terminal binding site. Nat Chem Biol 2012;8:78-85.

71 Beuers U: Drug insight: mechanisms and sites of action of ursodeoxycholic acid in cholestasis. Nat Clin Pract Gastroenterol Hepatol 2006;3:318-328.

72 Balistreri WF, Heubi JE, Whitington P, et al: Ursodeoxycholic acid therapy in pediatric hepatobiliary disease. Hepatology 1989;10: $602 \mathrm{~A}$
73 Narkewicz MR, Smith D, Gregory C, Lear JL, Osberg I, Sokol RJ: Effect of ursodeoxycholic acid therapy on hepatic function in children with intrahepatic cholestatic liver disease. J Pediatr Gastroenterol Nutr 1998;26:49-55.

74 Dinler G, Kocak N, Yuce A, Gurakan F, Ozen $\mathrm{H}$ : Ursodeoxycholic acid therapy in children with cholestatic liver disease. Turk J Pediatr 1999;41:91-98.

75 Chappell LC, Gurung V, Seed PT, Chambers J, Williamson C, Thornton JG: Ursodeoxycholic acid versus placebo, and early term delivery versus expectant management, in women with intrahepatic cholestasis of pregnancy: semifactorial randomised clinical trial. BMJ 2012;344:e3799.

76 Lindor KD: Ursodiol for primary sclerosing cholangitis. Mayo Primary Sclerosing Cholangitis-Ursodeoxycholic Acid Study Group N Engl J Med 1997;336:691-695.

77 Van Itallie TB, Hashim SA, Crampton RS, Tennent DM: The treatment of pruritus and hypercholesteremia of primary biliary cirrhosis with cholestyramine. N Engl J Med 1961 265:469-474.

78 Carey JB Jr, Williams G: Relief of the pruritus of jaundice with a bile-acid sequestering resin. JAMA 1961;176:432-435.

79 Oster ZH, Rachmilewitz EA, Moran E, Stein Y: Relief of pruritus by cholestyramine in chronic liver disease. Isr J Med Sci 1965;1: 599-606.

80 Datta DV, Sherlock S: Treatment of pruritus of obstructive jaundice with cholestyramine. Br Med J 1963;1:216-219.

81 Datta DV, Sherlock S: Cholestyramine for long term relief of the pruritus complicating intrahepatic cholestasis. Gastroenterology 1966;50:323-332.

82 Di Padova C, Tritapepe R, Rovagnati P, Rossetti S: Double-blind placebo-controlled clinical trial of microporous cholestyramine in the treatment of intra- and extrahepatic cholestasis: relationship between itching and serum bile acids. Methods Find Exp Clin Pharmacol 1984;6:773-776.

83 Duncan JS, Kennedy HJ, Triger DR: Treatment of pruritus due to chronic obstructive liver disease. Br Med J (Clin Res Ed) 1984;289: 22.

84 Pusl T, Beuers U: Extrahepatic manifestations of cholestatic liver diseases: pathogenesis and therapy. Clin Rev Allergy Immunol 2005;28: 147-157.
85 Kuiper EM, van Erpecum KJ, Beuers U, Hansen BE, Thio HB, de Man RA, Janssen HL, van Buuren HR: The potent bile acid sequestrant colesevelam is not effective in cholestatic pruritus: results of a double-blind, randomized, placebo-controlled trial. Hepatology 2010;52: 1334-1340.

86 Ghent CN, Carruthers SG: Treatment of pruritus in primary biliary cirrhosis with rifampin. Results of a double-blind, crossover, randomized trial. Gastroenterology 1988;94: 488-493.

87 Podesta A, Lopez P, Terg R, Villamil F, Flores D, Mastai R, Udaondo CB, Companc JP: Treatment of pruritus of primary biliary cirrhosis with rifampin. Dig Dis Sci 1991;36: 216-220.

88 Bachs L, Pares A, Elena M, Piera C, Rodes J: Comparison of rifampicin with phenobarbitone for treatment of pruritus in biliary cirrhosis. Lancet 1989;1:574-576.

89 Bachs L, Pares A, Elena M, Piera C, Rodes J: Effects of long-term rifampicin administration in primary biliary cirrhosis. Gastroenterology 1992;102:2077-2080.

90 Carson KL, Tran TT, Cotton P, Sharara AI, Hunt CM: Pilot study of the use of naltrexone to treat the severe pruritus of cholestatic liver disease. Am J Gastroenterol 1996;91:10221023.

-91 Wolfhagen FH, Sternieri E, Hop WC, Vitale G, Bertolotti M, Van Buuren HR: Oral naltrexone treatment for cholestatic pruritus: a double-blind, placebo-controlled study. Gastroenterology 1997;113:1264-1269.

$>92$ Terg R, Coronel E, Sorda J, Munoz AE, Findor J: Efficacy and safety of oral naltrexone treatment for pruritus of cholestasis, a crossover, double-blind, placebo-controlled study. J Hepatol 2002;37:717-722.

93 Mansour-Ghanaei F, Taheri A, Froutan H, Ghofrani H, Nasiri-Toosi M, Bagherzadeh AH, Farahvash MJ, Mirmomen S, EbrahimiDariani N, Farhangi E, Pourrasouli Z: Effect of oral naltrexone on pruritus in cholestatic patients. World J Gastroenterol 2006;12: 1125-1128.

94 Mayo MJ, Handem I, Saldana S, Jacobe H, Getachew Y, Rush AJ: Sertraline as a first-line treatment for cholestatic pruritus. Hepatology 2007;45:666-674.

95 Browning J, Combes B, Mayo MJ: Long-term efficacy of sertraline as a treatment for cholestatic pruritus in patients with primary biliary cirrhosis. Am J Gastroenterol 2003;98:27362741.
Advances in Pathogenesis and

Management of Pruritus in Cholestasis
Dig Dis 2014;32:637-645

DOI: $10.1159 / 000360518$ 